\title{
Effects of androgen and oestrogen on IGF pathways controlling phallus growth
}

\author{
Yu Chen¹, Hongshi Yu, Andrew J Pask¹, Asao Fujiyama², Yutaka Suzuki², Sumio Sugano ${ }^{3}$, \\ Geoff Shaw ${ }^{1}$ and Marilyn B Renfree ${ }^{1}$ \\ ${ }^{1}$ School of BioSciences, The University of Melbourne, Victoria, Australia, ${ }^{2}$ Advanced Genomics Center, National \\ Institute of Genetics, Mishima, Shizuoka, Japan and ${ }^{3}$ Department of Computational Biology and Medical Sciences, \\ Graduate School of Frontier Sciences, The University of Tokyo, Tokyo, Japan
}

Correspondence should be addressed to M B Renfree; Email: m.renfree@unimelb.edu.au

\begin{abstract}
The development of the mammalian phallus involves hormone-dependent mesenchymal-epithelial signalling mechanisms that contribute to urethral closure and regulation of phallus elongation and growth. In marsupials, most differentiation and growth of the phallus occurs post-natally, making them amenable to direct hormone treatment. Expression of IGFs, FGFs, EFNB2, MAFB, DLX5 and AP-1 mRNAs in the phallus at day 50 post-partum (pp) were altered after treatment of tammar wallaby young from day 20 to 40 pp with androgen, oestrogen or after castration at day $25 \mathrm{pp}$. However, the most interesting changes occurred in the IGF pathway genes. Androgen treatment upregulated IGF1 in female phalluses and oestrogen treatment upregulated IGF1 in male phalluses, but it was downregulated by castration. IGFBP3 was higher in female phalluses and downregulated by androgen. IGF1 expression was higher in all untreated male than in female phalluses from day 50 to $150 \mathrm{pp}$, but IGFBP3 had the reverse pattern. At day 90 pp, when urethral closure in males is progressing and male phallus growth is accelerating. IGF1 and PCNA protein were only detected in the male urorectal septum, suggesting for the first time that closure and elongation may involve IGF1 activation of cell proliferation specifically in male phalluses. These effects of sex steroids on gene expression and on the IGF1 signalling pathway in particular, suggest that the developing phallus may be especially susceptible to perturbation by exogenous hormones.

Reproduction (2019) $1571-12$
\end{abstract}

\section{Introduction}

Hypospadias is one of the most common developmental defects and currently affects approximately 1/125 male births in Western countries (Sweet et al. 1974), increasing by $2 \%$ each year in Western Australia (Paulozzi et al. 1997, Paulozzi 1999, Nassar et al. 2007). At least a proportion of this increase appears to be due to environmental endocrine disruptors (EEDs), such as insecticides, herbicides and many plastics (Suk Kim et al. 2004, Willingham et al. 2006, Fernandez et al. 2007, Vilela et al. 2007, Hsieh et al. 2008). Some androgenic EEDs masculinise the female phallus, resulting in an enlarged clitoris (Sane \& Pescovitz 1992, Wiig et al. 1998, Welsh et al. 2010). Hypospadias can also be induced in mammals by gene mutation or treatment with androgen inhibitors such as flutamide during development in utero (Wolf et al. 2000, Coveney et al. 2002, Leihy et al. 2002, 2004, Petiot et al. 2005, Seifert et al. 2008, Welsh et al. 2008, 2010, Chew et al. 2014, Zheng et al. 2015).

Urethral closure and differentiation of the phallus are under the regulation of complex gene networks. In mice, fibroblast growth factor 10 (FGF10) and its receptor fibroblast growth factor receptor 2 isoform IIIb (FGFR2IIIb) positively regulate genital tubercle (GT) outgrowth (Haraguchi et al. 2000, Satoh et al. 2004, Petiot et al. 2005, Gredler et al. 2015, Harada et al. 2015). Deletion of Fgf10 or Fgfr2IIIb results in abnormal urethra formation (Haraguchi et al. 2000, Satoh et al. 2004, Petiot et al. 2005, Gredler et al. 2015, Harada et al. 2015). FGF10, acting via the FGFR2IIlb receptor (Ornitz et al. 1996, Zhang et al. 2006), may direct epithelium-mesenchymal crosstalk and regulate GT patterning and urethral closure (Satoh et al. 2004, Gredler et al. 2015, Harada et al. 2015). EphrinB2 (EFNB2) is expressed in the ventral midline of the GT and cooperates with its receptor, tyrosine-protein kinase receptor $\mathrm{EPH}-3$ (EPHB2) through a directional signalling pathway to maintain normal urorectal development in mice (Adams 2002, Dravis et al. 2004, Yucel et al. 2007). If any part of the pathway is missing, severe hypospadias and urorectal malformations occur (Dravis et al. 2004, Yucel et al. 2007). V-Maf Avian Musculoaponeurotic Fibrosarcoma Oncogene Homologue B (Mafb), an androgen-dependent gene, is predominantly expressed in mesenchymal cells of male phalluses (Suzuki et al. 2014, Matsushita et al. 2015). In mice, its expression is 
upregulated in female GT mesenchyme after exogenous androgen treatment, but is downregulated in male GT mesenchyme of androgen receptor (Ar) knockouts (KO) (Suzuki et al. 2014). Mafb KOs in mice fail to form a urethra (Suzuki et al. 2014), suggesting a key role for Mafb in masculinization of the male phallus. Distal-Less Homeobox $5(D / x 5)$ is expressed in the developing urethral epithelium and GT mesenchyme in mice (Acampora et al. 1999, Merlo et al. 2004, Suzuki et al. 2008). In D/x5knockout mice, there is severe hypospadias and reduced testosterone during phallus development (Nishida et al. 2008, Suzuki et al. 2008).

The function of the activator protein-1 (AP-1) genes during phallus development has been less well studied. AP-1 proteins, including V-Jun Avian Sarcoma Virus 17 Oncogene Homolog (C-JUN), JunB ProtoOncogene (JUNB), JunB Proto-Oncogene (JUND), FBJ Murine Osteosarcoma Viral Oncogene Homolog (C-FOS), FBJ Murine Osteosarcoma Viral Oncogene Homolog B (FOSB), MAFB and Activating Transcription Factor 3 (ATF3) sub-families, control downstream gene expression to regulate cell proliferation, transformation and apoptosis (Vogt \& Bos 1990, Angel \& Karin 1991).

Insulin growth factor 1 (IGF1) plays an important role in regulating somatic growth in mammals including humans in whom it can affect phallus growth (Laron et al. 1966). It associates with a high-affinity-binding protein, insulin growth factor-binding protein 1-6 (IGFBP1-6) (Hwa et al. 1999). In humans, abnormal penile development seen in Laron syndrome can be improved by treatment with IGF1 (Levy \& Husmann 1996, Laron \& Klinger 1998). Binding proteins of IGF1 (IGFBPs) increase the lifespan of IGF1 in all tissues (Stewart et al. 1993, Kalus et al. 1998). Interestingly, IGFBP3 negatively regulates cell growth and proliferation through IGF-independent mechanisms (Schmid et al. 1991, Valentinis et al. 1995, Duan \& Xu 2005). In addition, IGF1 and IGFBP3 have differing responses towards androgen and oestrogen in human cell lines (Huynh et al. 1996, Le et al. 2006). Dihydrotestosterone and testosterone increase cell growth and IGF1 expression, but decrease IGFBP3 expression in human prostatic stromal cells (Le et al. 2006). Interestingly in the tammar wallaby Macropus eugenii, there is a significantly higher hepatic expression of IGFs in males than in females at day 70 pp, the time that the male phallus becomes sexually dimorphic, and IGF1 in the plasma rises steadily from day 50 to $250 \mathrm{pp}$ (Menzies et al. 2012).

Phallus differentiation in the tammar is initiated during an androgen 'window of sensitivity' that we first described occurs between day 20 and 40 post-partum (pp) (Leihy et al. 2004), and now refined to an even shorter period between day $25 \mathrm{pp}$ and day $30 \mathrm{pp}$ in the developing tammar pouch young (Chew et al. 2014). This is the same as the 'male programming window' subsequently described in the rat (Welsh et al. 2008, 2010) and human (Welsh et al. 2014). We have shown that phallus-regulating genes are not only sensitive to androgen but also to oestrogen during this programming (or androgen imprinting) window (Chew et al. 2014, Chen et al. 2018). Gonadal oestrogen in untreated young is below detection in both sexes between at least the day of birth and day $50 \mathrm{pp}$ (Renfree et al. 1992). Urethral closure and elongation in the tammar phallus are both androgen dependent (Leihy et al. 2004, Chew et al. 2014, Renfree et al. 2014, Chen et al. 2018), requiring at least a short-term exposure to androgen, while maintaining phallus elongation requires a constant level of androgen (Leihy et al. 2004, Renfree et al. 2014, Chen et al. 2018). Altering androgen or oestrogen in males during the window of sensitivity leads to abnormal phallus phenotypes and failed urethral closure (Leihy et al. 2004, Renfree et al. 2014, Chen et al. 2018). However, after oestrogen treatment, there is no change in androgen levels in treated males (Chen et al. 2018). In the tammar, the phallus does not become sexually dimorphic until after day $50 \mathrm{pp}$ and urethral closure is not complete until after day $150 \mathrm{pp}$ (Leihy et al. 2011). The tammar wallaby therefore provides a unique model in which to study the direct effects of hormonal manipulation on gene expression during phallus development without the complicating effects of maternal physiology and placental transfer. We therefore treated female tammars with androgen and males with oestrogen or castration during the androgen imprinting/male programming window of sensitivity, then used transcriptomic analysis and bioinformatic tools to identify the effects at day $50 \mathrm{pp}$. We also sampled normal phalluses at day 90 and $150 \mathrm{pp}$ when urethral closure is complete.

\section{Materials and methods}

\section{Animals}

Tammar wallabies (Macropus eugenii) of Kangaroo Island (South Australia) origin were held in our breeding colony. The sex of the pouch young was identified by the presence of scrotal budges (male) or mammary primordia (female) (Wai-Sum et al. 1988). The age of the pouch young was recorded from the day of birth or at later stages from head length using published growth curves (Poole et al. 1981). Phalluses were collected from pouch young tammar wallaby after anaesthesia with Zoletil 100 (Tiletamine $\mathrm{HCl} 50 \mathrm{mg} / \mathrm{mL}$, Zolazepam HCl $50 \mathrm{mg} / \mathrm{mL}$, Virbac, Cat\# 1p6080-3, $1 \mathrm{~mL} / \mathrm{kg}$ ) and killed by overdose of sodium pentobarbitone $(60 \mathrm{mg} / \mathrm{mL}$, to effect). Samples were snap-frozen and stored at $-80^{\circ} \mathrm{C}$ for RNA-Seq analysis or fixed in $4 \%(\mathrm{w} / \mathrm{v})$ paraformaldehyde, embedded in paraffin and cut into $7 \mu \mathrm{m}$ sections for histological analysis and section in situ hybridization. All experimental procedures complied with the Australian National Health and Medical Research Council (2013) guidelines and approved by the University of Melbourne Animal Experimentation Ethics Committees. Phalluses were collected as above from untreated young at day 20, day 30, day 50, day 90 and day $150 \mathrm{pp}$ males and females for qPCR (each stage $n=5$ ). 
Phalluses for immunohistochemical analysis $(n=3)$ were collected as above from day $90 \mathrm{pp}$ males and females. Male pouch young were castrated $(n=5)$ as previously described (Leihy et al. 2004, Renfree et al. 2009, Chew et al. 2014) or treated with oestrogen $(2.5 \mathrm{mg} / \mathrm{kg} /$ day $)$ orally from day $20 \mathrm{pp}$ to day $40 \mathrm{pp}(n=5)$ as previously described (Coveney et al. 2001). Female pouch young $(n=5)$ were injected intra-peritoneally with $5 \alpha$-androstane- $3 \alpha, 17 \beta$-diol (adiol, $10 \mathrm{mg} / \mathrm{kg} / \mathrm{week}$ ) from day $20 \mathrm{pp}$ to day $40 \mathrm{pp}$ as previously described (Leihy et al. 2004). Phalluses were collected at day $50 \mathrm{pp}(n=5)$ for RNASeq analysis and qPCR $(n=5)$.

\section{RNA extraction and CDNA preparation}

RNA was extracted from developing phalluses with the RNeasy Mini kit (Cat\# 74804 Qiagen) following on the manufacturer's recommendations. RNA concentration was calculated with a Qubit 2.0 fluorometer (ThermoFisher scientific). All RNA samples were treated with a DNA-free kit (Ambion, Cat \#1906) to prevent genomic DNA contamination. Two hundred nanograms of total RNA was used for cDNA template synthesis by using the transcription high fidelity cDNA Synthesis kit (Cat\# 05081963001, Invitrogen).

\section{RNA-Seq assembly and analysis}

RNA samples were further analysed using TapeStation (Agilent). Appropriate amounts of RNA were subjected to multiplex indexed-RNA-Seq analyses using TruSeq kit (Illumina) and HiSeq2500 analyzer (Illumina). Roughly $10-14 \times 10^{6}$ reads (100 bp) were obtained from each sample after Q.V. >30 filtering. The average quality score was $\sim 39$. The RNA-Seq data were assembled with Trimmomatic (Bolger et al. 2014) and Cufflinks-Cuffdiff (Trapnell et al. 2010) pipeline and analysed with CummeRbund R package (Goff et al. 2012). The average mapping rate from all samples was above $80 \%$ and the quality was good for differential expression analysis. The tammar wallaby genome 3.0 (T Heider, A Fujiyama, MB Renfree, AJ Pask and R O'Neill, personal communication) was used as a guide for RNA-Seq assembly. The annotation was obtained by blasting against the UNIPROT protein database (Apweiler et al. 2004). Differentially expressed genes were extracted with CummeRbund $\mathrm{R}$ package and basic $\mathrm{R}$ scripts (Team 2014).

\section{Quantitative PCR}

FastStart Universal SYBR mix (Roche, Cat\#04913914001) was used to detect gene expression levels. PCR primers (Supplementary Table 1, see section on supplementary data given at the end of this article) were designed with the online program Primer 3 (http://primer3.ut.ee/). The efficiency of each set of primers was within 95-105\%. The amplification conditions for qPCR were 1 cycle of $95^{\circ} \mathrm{C}$ for $10 \mathrm{~min}$; 45 cycles of $95^{\circ} \mathrm{C}$ for $30 \mathrm{~s}, 58^{\circ} \mathrm{C}$ for $30 \mathrm{~s}, 72^{\circ} \mathrm{C}$ for $1 \mathrm{~min}$ and 1 cycle of $72^{\circ} \mathrm{C}$ for $7 \mathrm{~min}$. All genes were run with triplicates. Three house-keeping genes (HMBS, 185 and GAPDH) were used to normalise the expression level according to MIQE guidelines (Bustin et al. 2009).

\section{Section in situ hybridization}

Phalluses for section in situ hybridization were collected from day $20 \mathrm{pp}$ and day $90 \mathrm{pp}$ pouch young $(n=3)$. The paraffin-embedded phalluses were sectioned at $7 \mu \mathrm{m}$. Primers (Supplementary Table 2) were designed with the program Primer 3 online (http://primer3.ut.ee/). The probes for situ hybridization (ISH) were labelled with DIG RNA labelling Mix (Roche, Cat\#11277073910) and generated with T7/ SP6 polymerase synthase kit (Promega, Cat \#P1460). The sections were pre-hybridized for $2 \mathrm{~h}$ at $42^{\circ} \mathrm{C}$ and hybridized for $16-18 \mathrm{~h}$ at $42^{\circ} \mathrm{C}$. Then, the sections were washed and incubated with anti-digoxigenin-AP (1:300 dilution, Roche, Cat \#11093274910) for $16-18 \mathrm{~h}$ at $4^{\circ} \mathrm{C}$ and colour developed with NBT/BCIP (1:50 dilution, Roche, Cat \#11681451001). The sections were counter-stained with Nuclear Fast Red solution (Sigma Aldrich, Cat \#N3020). Negative controls were incubated with sense probe (Supplementary Fig. 1 and data not shown). Photos were taken with an Olympus BX51 Fluorescence Microscope and Olympus DP70 Camera System.

\section{Immunofluorescence}

The paraffin-embedded phalluses were sectioned at $7 \mu \mathrm{m}$. The sections were de-paraffinized with histolene and rehydrated with serial dilutions with ethanol. Antigen retrieval was performed by heating in $30 \%$ power of a microwave $(1000 \mathrm{~W})$ for $20 \mathrm{~min}$ in $0.01 \mathrm{~mol} / \mathrm{L}$ sodium citrate buffer ( $\mathrm{pH}$ 10) for IGF1. No antigen retrieval was performed for proliferating cell nuclear antigen (PCNA), a marker of cell proliferation. The primary antibody, IGF1 (rabbit polyclonal, 1:100 dilution, GroPep Bioreagents, Cat\# PAA2) or PCNA (rabbit polyclonal, 1:30 dilution, Santa Cruz Biotechnology, Cat\# sc-7907) were added to the section and incubated at $4^{\circ} \mathrm{C}$ overnight. The negative controls were incubated with rabbit immunoglobulin fraction (Dako, Cat\# X0903) without primary antibody. The secondary antibody donkey antirabbit IgG (Supplementary Table 3) was performed at room temperature for $1 \mathrm{~h}$. DAPI $(1: 10,0005 \mathrm{mg} / \mathrm{mL}$, Invitrogen, Cat\# D3571) was used as a nuclear counterstain. Fluorescent mounting medium (Dako, Cat\# S302380) was used for mounting. The edges of coverslips were sealed with nail polish and stored at $4^{\circ} \mathrm{C}$ in the dark.

\section{Statistical analysis}

Three biological replicates were used for immunofluorescence and section in situ hybridisation. Five biological replicates were used for qPCR and RNA-Seq analysis. FPKM (Fragments

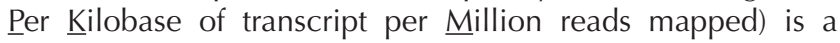
normalised estimation of gene expression based on RNASeq data. FPKM are calculated from the number of reads that mapped to each particular gene sequence taking into account the gene length and the sequencing depth. Three housekeeping genes were used for qPCR calculation based on MIQE guidelines (Bustin et al. 2009). Student's $t$-test was used to calculate the significance $(* P<0.05, * * P<0.05$, $* * * P<0.001)$ of normalized RNA-Seq data and qPCR data. All error bars represent the standard error of the mean (S.E.M.). 


\section{Results}

\section{Conserved mRNA localization of FGF10, FGFR2-IIIB, EFNB2, MAFB and DLX5}

The mRNA distribution of FGF10, FGFR2-IIIB, EFNB2, $M A F B$ and $D L X 5$ was conserved with those of eutherian mammals during phallus development. FGF10 and its receptor FGFR2-IIIB were co-localised in the urethral epithelium and phallus epithelium in both male and female phalluses at day $20 \mathrm{pp}$ and day $90 \mathrm{pp}$ (Figs 1 and 2). EFNB2 was detected in the urethral epithelium and phallus epithelium in the phallus at day $20 \mathrm{pp}$ and day $90 \mathrm{pp}$ (Figs 1 and 2). EFNB2 mRNA was also found in mesenchymal cells around the urethral epithelium in phalluses at day $20 \mathrm{pp}$ (Fig. 1). MAFB was mainly found in the epithelium and corpora cavernosa (Figs 1 and 2). DLX5 mRNA was detected primarily in the urethral epithelium (Figs 1 and 2). Mesenchymal staining of $D L X 5$ was found in male phalluses at day $20 \mathrm{pp}$ and day $90 \mathrm{pp}$ (Figs 1 and 2).

\section{Hormonal responsiveness and expression pattern of FGF10, FGFR2-IIIB, EFNB2, MAFB and DLX5 during phallus differentiation}

RNA-Seq expression of FGF10 and EFNB2 was higher in male phalluses than female phalluses at day $50 \mathrm{pp}$ (Fig. 3). They were both upregulated after adiol treatment in female phalluses but downregulated by castration in males (Fig. 3). In males, FGF10 was not affected by oestrogen treatment, but EFNB2 was downregulated (Fig. 3). MAFB was higher in untreated female phalluses than male phalluses at day $50 \mathrm{pp}$ (Fig. 3) but was upregulated in male phalluses at day $50 \mathrm{pp}$ after castration. MAFB expression did not change after treatment with either adiol or oestrogen (Fig. 3) and FGFR2-IIIB and DLX5 did not change after adiol treatment, oestrogen treatment or castration (data not shown).

In untreated phalluses, there were no significant changes in expression of FGF10, FGFR2-IIIB, EFNB2 and DLX5 measured by qPCR between male and female phalluses before day $50 \mathrm{pp}$ (Fig. 4), but MAFB was higher in female phalluses than male phalluses at this stage. By day 90 pp, FGF10, FGFR2-IIIB, DLX5, EFNB2 and $M A F B$ were all significantly higher in male than in female phalluses at day $90 \mathrm{pp}$ (Fig. 4).

\section{Androgen dependent AP-1 genes}

$A P-1$ genes, including C-FOS, FOSB, C-JUN, JUNB, JUND and ATF3 mRNA were all significantly higher in male than in female phalluses at day $50 \mathrm{pp}$ and were all significantly upregulated after adiol treatment. Within the AP-1 genes, only C-FOS was downregulated after oestrogen treatment of males (Fig. 5).

\section{Distribution of IGF1 and PCNA during phallus elongation}

In day $90 \mathrm{pp}$ male and female phalluses, IGF1 was predominantly localised in the extracellular matrix and cell membranes of the urethral epithelium, phallus epithelium and corpora cavernosa (Fig. 6). Some staining also occurred in the cytoplasm of urethral epithelial cells and phallus epithelial cells (Fig. 6). Interestingly, IGF1 was identified in the extracellular matrix and cytoplasm of mesenchymal cells of only the male urorectal septum (URS) at day $90 \mathrm{pp}$ (Fig. 6). Staining of day $90 \mathrm{pp}$ phalluses with PCNA antibody showed that the protein was localised in the nucleus of the basal urethral epithelial cells, the phallus epithelial cells and mesenchymal cells of the corpora cavernosa (Fig. 7), with a small amount of staining in the cytoplasm and

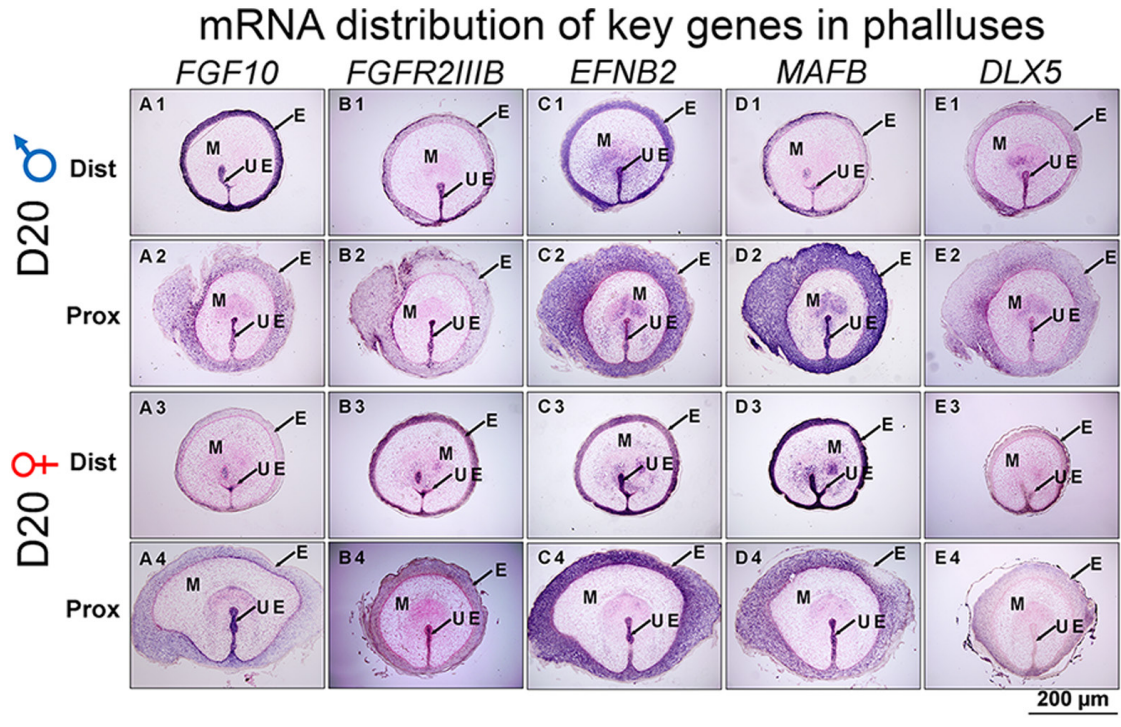

Figure 1 mRNA distribution of FGF10, FGFR2IIIb, EFNB2, MAFB and DLX5, in day $20 \mathrm{pp}$ male and female phalluses irrespective of sex, mRNA of FGF10, FGFR2IIIb, EFNB2, $M A F B$ and $D L X 5$ were all detected in the urethral epithelial cells and phallus epithelial cells in the phalluses at day $20 \mathrm{pp}$. EFNB2, $M A F B$ and $D L X 5$ were also expressed in the mesenchyme in male and female phalluses. Section in situ hybridisation staining of FGF10 (A1-A4), FGFR2IIIb (B1-B4), EFNB2 (C1-C4), MAFB (D1-D4) and DLX5 (E1-E4). E, epithelium; M, mesenchyme; UE, urethral epithelium; Dist, distal; Prox, proximal. Scale bar: $200 \mu \mathrm{m}$. 


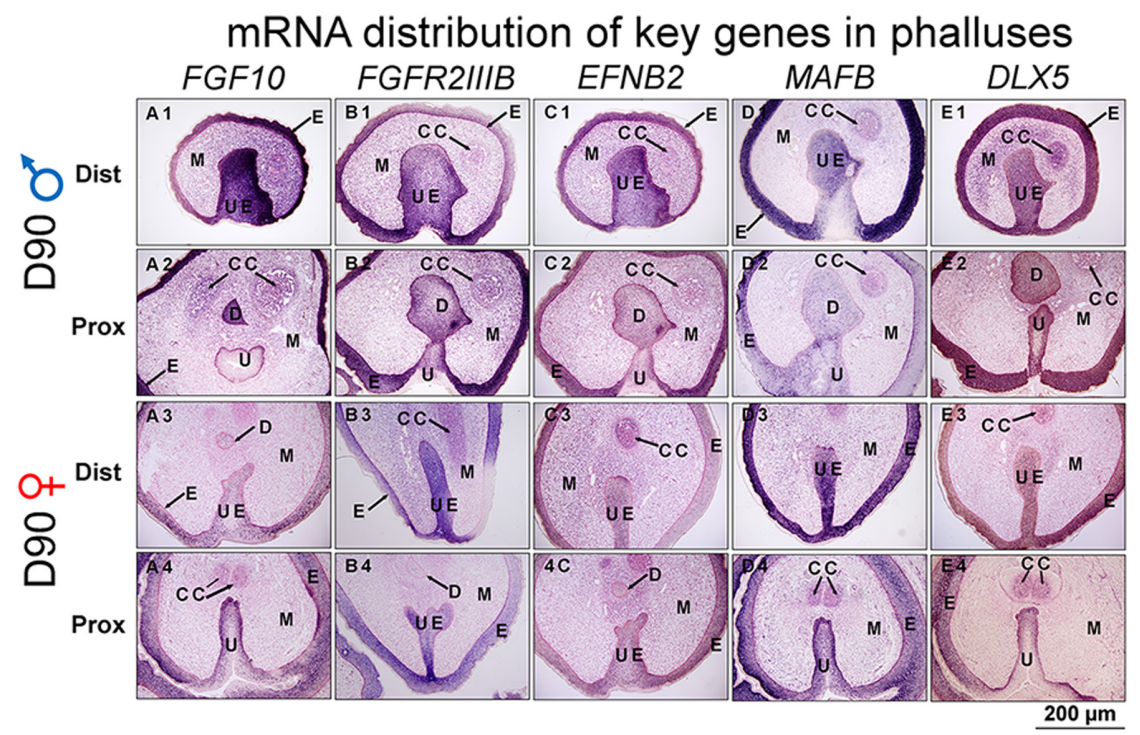

Figure 2 mRNA distribution of FGF10, FGFR2IIIb, EFNB2, MAFB and DLX5, in day $90 \mathrm{pp}$ male and female phalluses. Irrespective of sex, mRNA of FGF10, FGFR2IIIb, EFNB2, $M A F B$ and $D L X 5$ were all detected in the urethral epithelial cells and phallus epithelial cells in the phalluses. FGF1O and DLX5 were expressed in the mesenchyme in male phalluses at day $90 \mathrm{pp}$. The urethral closure is complete at the base of male phalluses at this stage. There is a slight variation in sectioning depth shown in the proximal sections of phalluses, so apparent differences in the degree of urethral closure are due to the level of sectioning used. Section in situ hybridisation staining of FGF10 (A1-A4), FGFR2IIIb (B1-B4), EFNB2 (C1-C4), MAFB (D1-D4) and DLX5 (E1-E4). D, diverticulum; E, epithelium; M, mesenchyme; $U$, urethra; UE, urethral epithelium; Dist, distal; Prox, proximal. Scale bar: $200 \mu \mathrm{m}$. extracellular matrix of urethral epithelial cells, phallus epithelial cells and mesenchymal cells (Fig. 7). Similarly, the nuclear PCNA was only found in mesenchymal cells of the male URS in phalluses at day $90 \mathrm{pp}$ but not in that of female phalluses (Fig. 7).

\section{Hormonally responsive IGF1, IGFBP3 and IGFBP6}

From the RNA-Seq and qPCR data, IGF1 expression was higher in untreated male phalluses than female phalluses at day $50 \mathrm{pp}$, at day $90 \mathrm{pp}$ and day $150 \mathrm{pp}$ (Fig. 8). It was upregulated after adiol treatment in females and oestrogen treatment in males, but downregulated after castration in males at day $50 \mathrm{pp}$ (Fig. 8). IGFBP6 was also upregulated after adiol treatment in females and oestrogen treatment in males (Fig. 8). In contrast, IGFBP3 was higher in untreated female phalluses than male phalluses at day $50 \mathrm{pp}$, day $90 \mathrm{pp}$ and day $150 \mathrm{pp}$
(Fig. 8) and downregulated by adiol treatment in females at day $50 \mathrm{pp}$ (Fig. 8).

\section{Discussion}

Differentiation and growth of the phallus depends on a suite of genes that have specific spatial and temporal expression patterns. Sex steroids are critical to this process and control gene expression. FGF10, EFNB2 and $M A F B$ were affected by both androgen and oestrogen treatments, while $A P-1$ genes appear to be solely under the control of androgen. The complimentary expression patterns of IGF1 and the receptor IGFBP3 suggest that the balance of these two genes might be key to understand urethral closure and phallus elongation, which may be mediated by IGF1-induced rapid proliferation of cells in the urorectal septum and urethral epithelia.
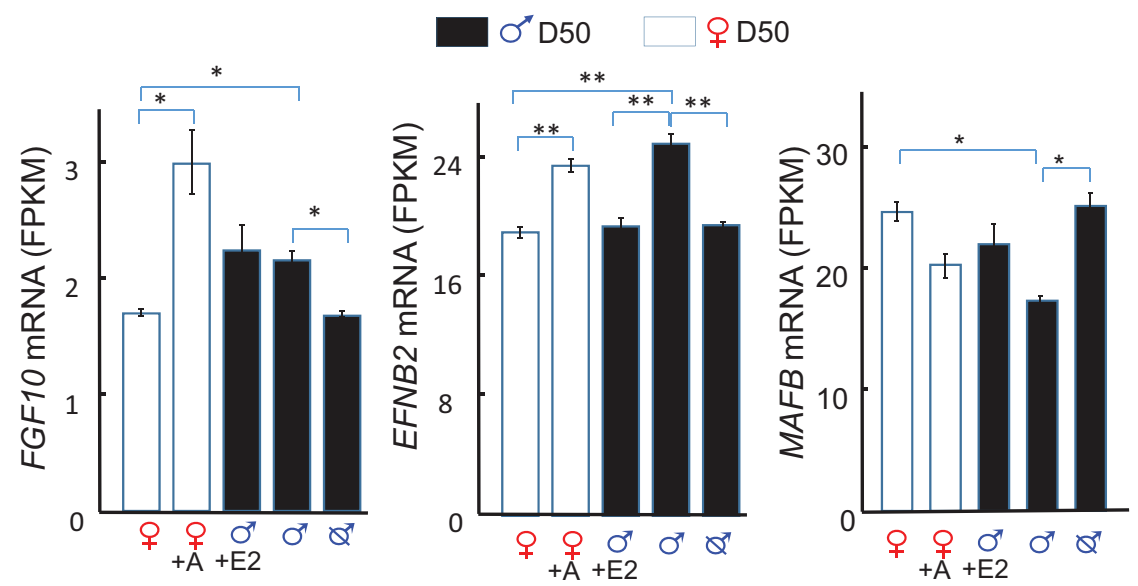

Figure 3 Transcriptomic expression of FGF10, EFNB2 and MAFB in normal and hormone treated phalluses at day $50 \mathrm{pp}$. FGF10 was higher in male phalluses than female phalluses at day $50 \mathrm{pp}$, upregulated in female phalluses after androgen treatment, and downregulated in males after castration. EFNB2 expression was higher in male phalluses than female phalluses at day $50 \mathrm{pp}$, upregulated in female phalluses after androgen treatment and downregulated in males after oestrogen treatment or castration. MAFB expression was higher in female phalluses at day $50 \mathrm{pp}$ than that in male phalluses, upregulated after castration in males, but not affected by androgen treatment nor oestrogen treatment. A, androgen; E2, oestrogen; FPKM, Fragments Per Kilobase of transcript per Million mapped reads. ${ }^{*} P<0.05,{ }^{*} P<0.05$. Error bar: S.E.M. 

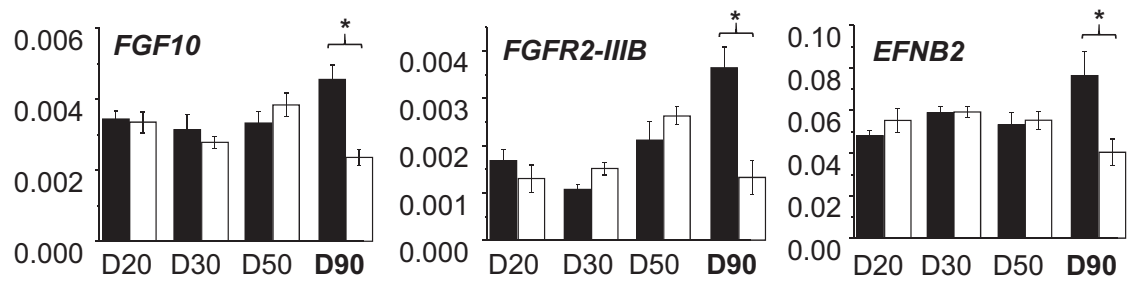
Figure $4 \mathrm{qPCR}$ analysis on the expression of FGF10, FGFR2IIIb, EFNB2, MAFB and DLX5 during postnatal phallus development. The expression level of FGF10, FGFR2IIIb, EFNB2, $M A F B$ and DLX5 was significantly higher in male phalluses than in female phalluses at day $90 \mathrm{pp}$. The expression of FGF10 and EFNB2 were similar from day $20 \mathrm{pp}$ to day $90 \mathrm{pp}$. There was no differences in expression level between male phalluses and female phalluses until after day $50 \mathrm{pp}$. MABF was significantly higher in female phalluses at day 50 pp. DLX5 was significantly reduced in the female phalluses at day $90 \mathrm{pp}$. The expression of all genes was relative to 185, GAPDH and HMBS. $* P<0$.05. Error bar: S.E.M.

FGF10, FGFR2IIIb, EFNB2, MAFB and DLX5 were all expressed in the urethral epithelium as well as in the phallus epithelium in the tammar, as shown in mice (Haraguchi et al. 2001, Perriton et al. 2002, Dravis et al. 2004, Petiot et al. 2005, Gredler et al. 2015, Harada et al. 2015). In mice, these genes are all crucial for maintaining cell proliferation and cell survival in the phallus (Bhushan et al. 2001, Shaulian \& Karin 2001, Bendall et al. 2003, Hart et al. 2003, Steinberg et al. 2005, Weiler et al. 2009, Yu et al. 2016). FGF10 expression increased after androgen treatment in phalluses at day $50 \mathrm{pp}$ in the tammar. A similar effect of androgen on FGF10 expression also occurs in prostate cancer cells (Lu et al. 1999, Nakano et al. 1999, Donjacour et al. 2003) and in cultured mice phalluses in which FGF10 expression is downregulated after adding the anti-androgen flutamide (Petiot et al. 2005). EFNB2 expression was also increased after androgen treatment, but was downregulated by oestrogen and by castration in males. Interestingly, the opposite effect occurs in castrated mice in which EFNB2 is downregulated in the epididymis after treating with testosterone propionate (Snyder et al. 2009). However, it is known that the hormonal responsiveness of EFNB2 is different in different tissues (Nikolova et al. 1998, Yucel et al. 2007, Snyder et al. 2009) so both androgen and oestrogen can influence its action.

$M A F B$ was significantly higher in female phalluses at day $50 \mathrm{pp}$ and upregulated after castration. However, $M A F B$ subsequently increased in male phalluses and became higher than that in female phalluses by day $90 \mathrm{pp}$. This was not expected since the expression of Mafb is upregulated in male phalluses in mice, but these were sampled before E18.5, well before the male phallus growth and elongation takes place (Suzuki et al. 2014, Matsushita et al. 2015). Interestingly, from our previous studies in the tammar, $\mathrm{SHH}$ was significantly higher in female phalluses between day 30 and day $40 \mathrm{pp}$ but lower in female phalluses between day 50 to day $60 \mathrm{pp}$ (Chew et al. 2014). The expression pattern of $S H H$ was very similar to that of $M A F B$, with one difference that the change of $S H H$ expression occurred about 10 days earlier. It is possible that MAFB may be a downstream target of $\mathrm{SHH}$ signalling under the negative regulation of androgen. In addition, Mafb expression is also controlled by $\beta$-catenin, the transcription factor of Wingless-Type MMTV Integration Site Family, Member (WNT)/ $\beta$-catenin pathway (Matsushita et al. 2015).
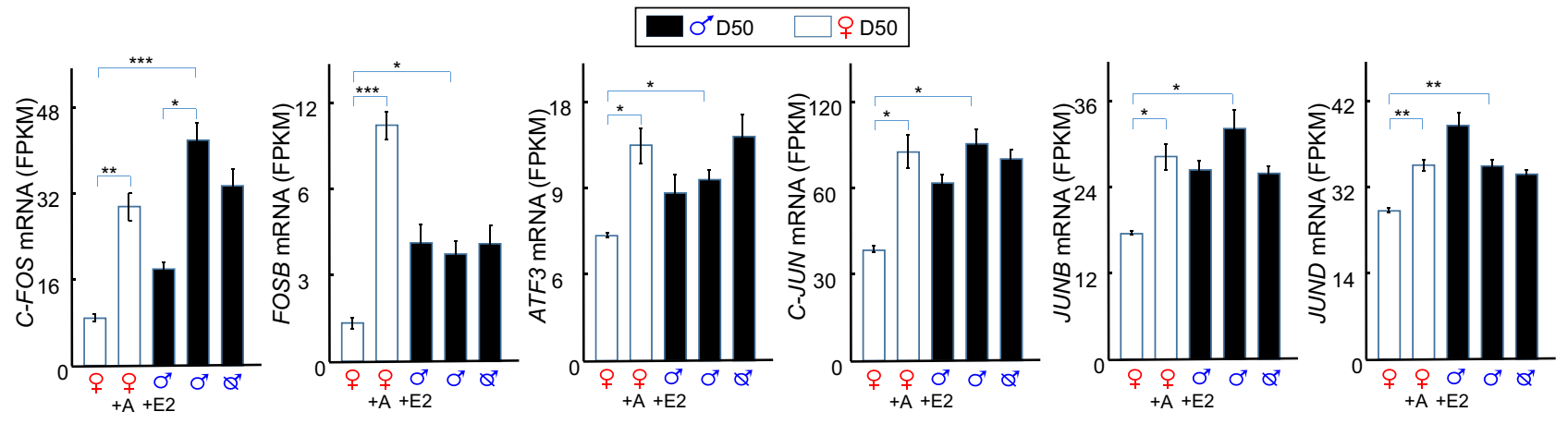

Figure 5 RNA-Seq analysis on the expression pattern of AP-1 genes in phalluses at day 50pp. The expression of C-FOS, FOSB, ATF3, C-JUN, JUNB and JUND were increased after androgen treatment. The expression level of those genes was significantly higher in male phalluses at day

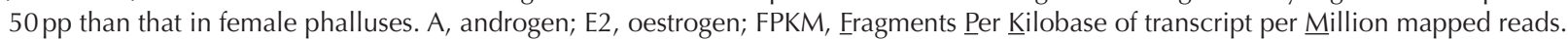

$* P<0.05, * * P<0.05, * * * P<0.001$. Error bar: S.E.M. 


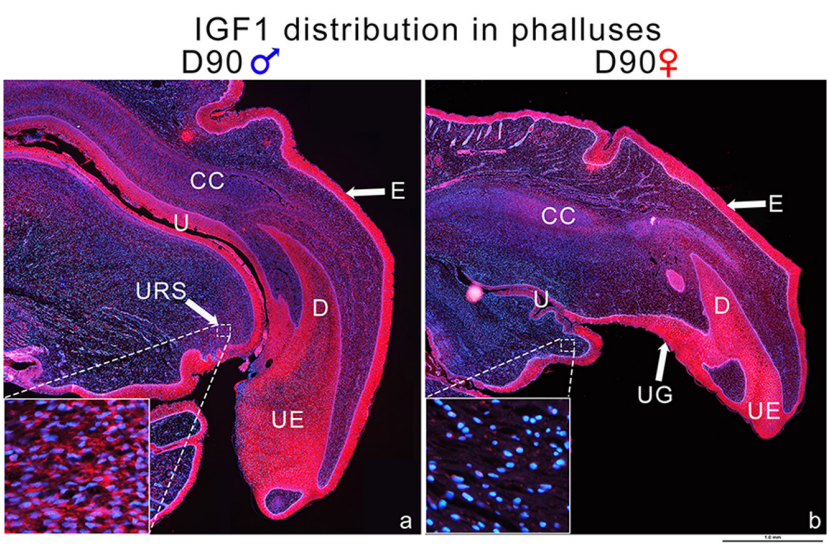

Figure 6 IGF1 distribution in male and female phalluses at day $90 \mathrm{pp}$. In both male and female phalluses, IGF1 was primarily found in the extracellular matrix and cytoplasm of epithelial cells and in the diverticulum. Some IGF1 was detected in the corpora cavernosa. In the URS, IGF1 was found only in male phalluses (see insets). CC, corpus cavernosum; D, diverticulum; E, epithelium; U, urethra; UE, urethral epithelium; UG, urethra groove; URS, urorectal septum. Red staining: IGF1. Blue staining: DAPI. Scale bar: $1.0 \mathrm{~mm}$.

$\mathrm{SHH}$, upstream of $\mathrm{WNT} / \beta$-catenin signaling, regulates cell proliferation by controlling WNT/ $\beta$-catenin activity during GT outgrowth in mice (Miyagawa et al. 2009).

In the tammar, $A P-1$ genes have higher expression in males and were upregulated in females after androgen treatment at day $50 \mathrm{pp}$ (Fig. 9). Similarly, androgen induces c-Fos expression in the rat hippocampus (Kerr et al. 1996) and upregulates ATF3 expression in human prostate cancer cells (Pelzer et al. 2006). In addition, androgen induces the AP-1 DNA-binding and transcriptional activity in human prostate carcinoma cells (Church et al. 2005). AP-1 genes regulate cell proliferation (reviewed in (Angel \& Karin 1991), and since androgen treatment can induce phallus elongation (Leihy et al. 2004) and urethral closure (Chen et al. 2018) in the tammar, it is likely that $A P-1$ genes contribute to this. C-FOS was affected by oestrogen treatment in males, suggesting a possible target of oestrogenic EEDs during phallus development, at least in the tammar.

The strong expression of the growth factor IGF1 in the URS, urethral and phallus epithelia, accompanying the rapid proliferation in those tissues in the male phallus was not expected. PCNA, a marker of proliferation known to regulate cell survival (Witko-Sarsat et al. 2010), was also strongly expressed in nuclei of male URS, urethral and phallus epithelia. IGF1 and nuclear PCNA were detected in the urorectal septum of only male, but not female phalluses, suggesting that IGF1 might induce urethral closure by regulating URS proliferation, between at least day 90 to day 150 when closure is complete (Fig. 9).

IGF1 was consistently more highly expressed in male than in female phalluses at day $50 \mathrm{pp}$, day $90 \mathrm{pp}$ and day $150 \mathrm{pp}$. In females, its expression was upregulated after androgen treatment. Clearly, IGF1 is androgen dependent in the tammar during phallus differentiation. Such androgenic dependency of IGFI is conserved with eutherian mammals, as IGF1 mRNA increases after testosterone treatment in bovine muscle satellite cells (Kamanga-Sollo et al. 2004), rat uterine tissue (Sahlin et al. 1994) and human prostate cancer cell lines (Arnold et al. 2005, Le et al. 2006). However, IGF1 has not previously been reported in the URS.

After oestrogen treatment, IGF1 was significantly upregulated in male phalluses (Fig. 9). Similarly, oestrogen also increases IGF1 expression in the primate cerebral cortex (Cheng et al. 2001) and in mice uteri (Hewitt et al. 2010). IGFBP6 had similar androgen and oestrogen responsiveness as IGF1.

This androgen and oestrogen responsiveness of IGFBP6 is also seen in other species (Koike et al. 2005, Henderson et al. 2006), including in the rat epididymis after inhibiting of dihydrotestosterone (DHT) (Henderson et al. 2006), and in prostate cancer cells after treatment with the synthetic oestrogen diethylstilboestrol (DES) (Koike et al. 2005). In contrast,
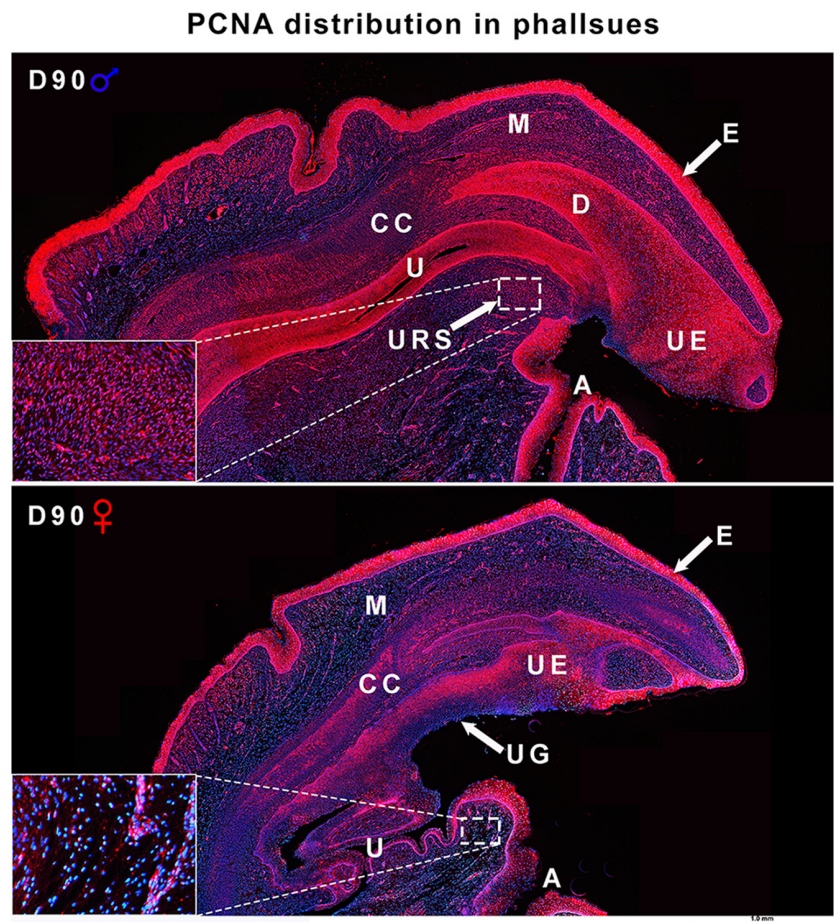

Figure 7 PCNA localisation in male and female phalluses at day $90 \mathrm{pp}$. In both male and female phalluses, PCNA staining was found in the nuclear of basal urethral epithelial cells, phallus epithelial cells and diverticulum. The nuclear PCNA was also found in mesenchymal cells in the corpora cavernosa. In the URS, nuclear PCNA was found only in male phalluses (see insets). Cytoplasmic PCNA was detected in the urethral epithelium, phallus epithelium and diverticulum in both sexes, and there was some mesenchymal cytoplasmic and extracellular matrix staining. A, anus; CC, corpus cavernosum; D, diverticulum; E, epithelium; $M$, mesenchyme; $U$, urethra; UE, urethral epithelium; UG, urethra groove; URS, urorectal septum. Red staining: PCNA. Blue staining: DAPI. Scale bar: $1.0 \mathrm{~mm}$. 

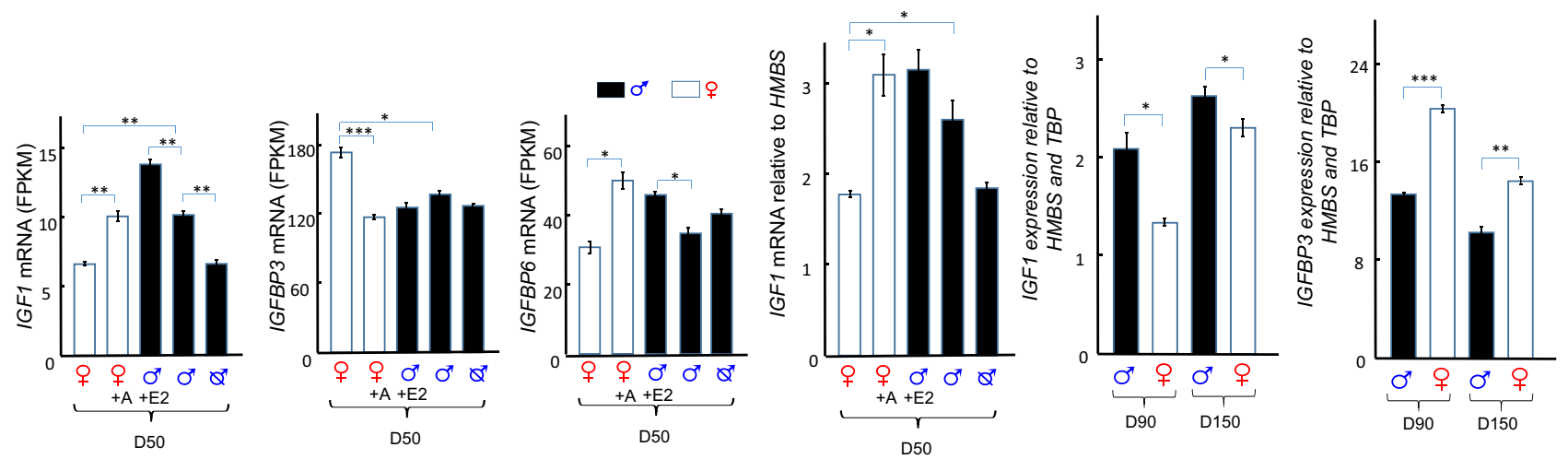

Figure 8 Expression pattern of IGF1, IGFBP3 and IGFBP6 in the phalluses. In RNASeq data (left), IGF1 was higher in male phalluses than female phalluses at day $50 \mathrm{pp}$. It was upregulated after androgen treatment in females and oestrogen treatment in males but was downregulated after castration in males. IGFBP3 was higher in female phalluses than male phalluses at day $50 \mathrm{pp}$. It was downregulated after androgen treatment in females. IGFBP6 was both upregulated in males after oestrogen treatment and in females after androgen treatment. In qPCR (right), IGF1 was higher in male phalluses than female phalluses at day $50 \mathrm{pp}$, day $90 \mathrm{pp}$ and day $150 \mathrm{pp}$. It was upregulated after androgen treatment in females but was not affected by oestrogen treatment or castration at day $50 \mathrm{pp}$. IGFBP3 was higher in female phalluses than male phalluses at day $50 \mathrm{pp}$, day $90 \mathrm{pp}$ and day $150 \mathrm{pp}$. A, androgen; E2, oestrogen; FPKM, Fragments Per Kilobase of transcript per Million mapped reads. ${ }^{*} P<0.05$,

$* * P<0.05,{ }^{* * *} P<0.001$. Error bar: S.E.M.

IGFBP3 has the opposite expression pattern to that of IGF1 in the tammar phalluses. It has higher expression in female phalluses than male phalluses at days 50, 90 and $150 \mathrm{pp}$, and its downregulation after androgen treatment in females are consistent with ligand (IGF1) receptor (IGFBP3) interactions. A similar pattern occurs in prostate cancer cells after treatment with androgen (Kojima et al. 2006, Peng et al. 2008) or synthetic androgen (Peng et al. 2008).

The complimentary expression patterns of IGF1 and IGFBP3 suggest that IGF1 might be a largely unrecognised growth factor in phalluses that activates cell proliferation, while IGFBP3 negatively regulates cell growth and proliferation in females, as seen in many other studies (Schmid et al. 1991, Valentinis et al. 1995, Grimberg \& Cohen 2000, Pollak 2000, Duan \& Xu 2005, Le et al. 2006). IGFBP3 activates protein tyrosine phosphatase (PTPase), so reversing the autophosphorylation of insulin-like growth factor 1 receptor (IGF1R) and tyrosine phosphorylation of insulin receptor substrate 1 (IRS1) (Duan \& Xu 2005). In addition, IGF1 and IGFBP3 have different responsiveness towards androgen
Response of IGF1, IGFBPs, FGF10, EFNB2, MAFB, AP-1 genes to steroid treatment

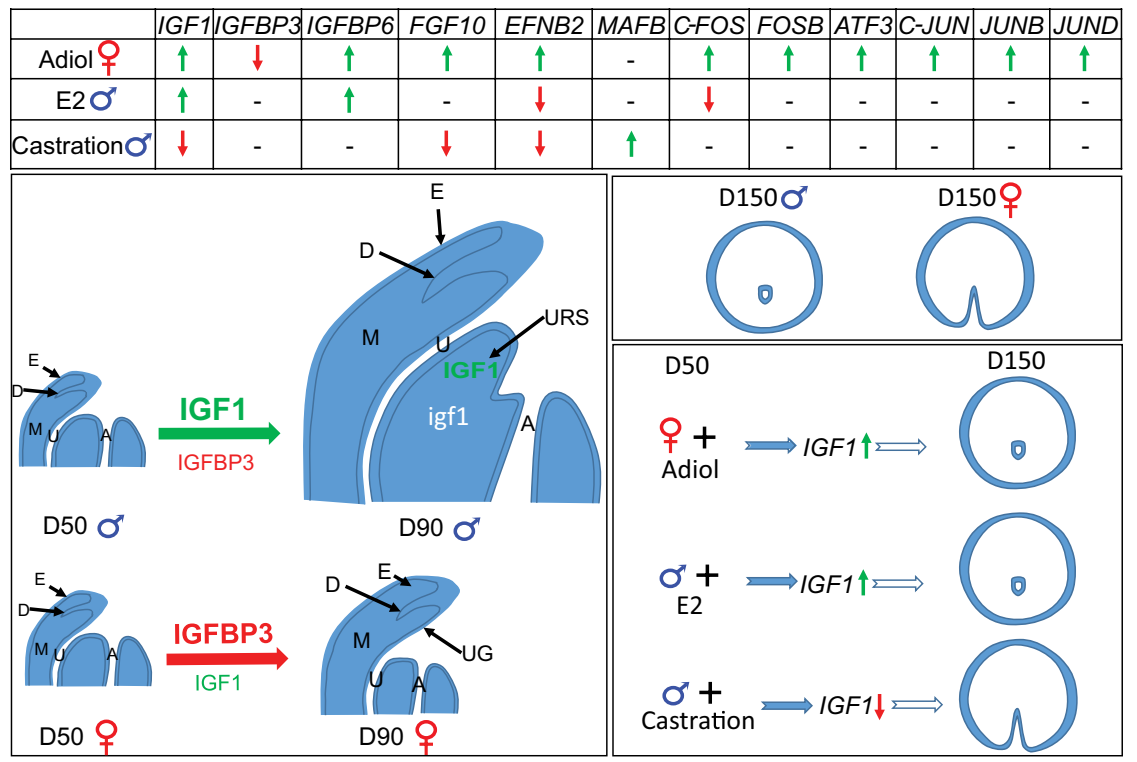

Figure 9 Summary of androgen and oestrogen effects on gene expression of IGF1, IGFBPS, FGF10, EFNB2, MAFB and $A P-1$ in phalluses (top) and diagram of how IGF1 regulates urethral closure (bottom). Adiol treatment upregulated gene expression of IGF1, IGFBP6, FGF10, EFNB2 and AP-1, but downregulated IGFBP3 expression. Oestrogen increased IGF1 and IGFBP6 expression but decreased EFNB2 and $C-F O S$ expression. Castrating males induced an upregulation of $M A F B$ and a downregulation of IGF1, FGF10 and EFNB2 in phalluses. IGF1 was higher in male phalluses from day $50 \mathrm{pp}$ to day $90 \mathrm{pp}$, and induced URS proliferation and urethral closure. In contrast, IGFBP3 was higher in female phalluses and inhibited urethral closure. Adiol treatment and oestrogen treatment both increased IGF1 expression and induced urethral closure of day $150 \mathrm{pp}$ phalluses. Castrating males decreased IGF1 expression in phalluses and prevented urethral closure. A, anus; D, diverticulum; E, epithelium; E2, oestrogen; $M$, mesenchyme; $U$, urethra; UG, urethral groove. Red indicates decreased levels; green indicates increased levels. 
and oestrogen in human cell lines (Huynh et al. 1996, Le et al. 2006). Dihydrotestosterone and testosterone increase cell growth and the expression of IGF1, but decrease IGFBP3 expression level in human prostatic stromal cells (Le et al. 2006). Oestrogen increases IGF1 expression in primate cerebral cortex (Cheng et al. 2001), but downregulates IGFBP3 expression in human breast cancer cells (Huynh et al. 1996). In addition, fulvestrant, an anti-oestrogen, increases IGFBP3 mRNA abundance and its protein accumulation in human breast cancer cells (Huynh et al. 1996). Therefore, maintaining a balance of IGF1 and IGFBP3 might be important for normal phallus development in the tammar. Both IGF1 and IGFBP6 were upregulated in male phalluses at day $50 \mathrm{pp}$ after oestrogen treatment. However, gonadal oestrogen at this stage in untreated young is below detection in both sexes (Renfree et al. 1992), so while this is unlikely to be a physiological effect, it highlights the possibility that both IGF1 and IGFBP6 could be potential targets of oestrogenic EEDs, such as DES, atrazine and bisphenols.

\section{Conclusions}

All the genes examined were affected by exogenous steroids during phallus development in the tammar. The conserved localisation and increased expression of FGF10, FGFR2IIIb, EFNB2, MAFB, DLX5 and AP-1 genes suggest that androgen influences cell proliferation and apoptosis to maintain phallus growth and elongation in the tammar as in eutherian mammals. In particular, IGF1 appears to induce urethral closure by activating cell proliferation in the urorectal septum of male phalluses, while IGFBP3 may negatively regulate this process. Thus, complex gene regulatory systems under the control of both androgenic and oestrogenic steroid hormones during phallus development and the effects on the IGF1 signalling pathway in particular suggest that the developing phallus may be especially susceptible to exogenous sex steroids.

\section{Supplementary data}

This is linked to the online version of the paper at https://doi.org/10.1530/REP-18-0416.

\section{Declaration of interest}

The authors declare that there is no conflict of interest that could be perceived as prejudicing the impartiality of the research reported.

\section{Funding}

This study was supported by a grant from the National Health and Medical Research Council of Australia to M B R, A J P, G S, HY and J D W.

\section{Acknowledgements}

The authors thank members of the Wallaby research group (Walgroup) for assistance when handling animals and Brianne Keane for assistance with PCNA staining. They also thank members of Advanced Genomics Center, NIG, for the technical support on RNA sequencing.

\section{References}

Acampora D, Merlo GR, Paleari L, Zerega B, Postiglione MP, Mantero S, Bober E, Barbieri O, Simeone A \& Levi G 1999 Craniofacial, vestibular and bone defects in mice lacking the Distal-less-related gene Dlx5. Development 126 3795-3809.

Adams RH. 2002 Vascular patterning by Eph receptor tyrosine kinases and ephrins. Seminars in Cell and Developmental Biology 13 55-60. (https:// doi.org/10.1006/scdb.2001.0289)

Angel P \& Karin M 1991 The role of Jun, Fos and the AP-1 complex in cellproliferation and transformation. Biochimica et Biophysica Acta (BBA): Reviews on Cancer 1072 129-157. (https://doi.org/10.1016/0304419x(91)90011-9)

Apweiler R, Bairoch A, Wu CH, Barker WC, Boeckmann B, Ferro S, Gasteiger E, Huang H, Lopez R \& Magrane M 2004 UniProt: the universal protein knowledgebase. Nucleic Acids Research 32 D115D119. (https://doi.org/10.1093/nar/gkh131)

Arnold JT, Le H, McFann KK \& Blackman MR 2005 Comparative effects of DHEA vs. testosterone, dihydrotestosterone, and estradiol on proliferation and gene expression in human LNCaP prostate cancer cells. American Journal of Physiology: Endocrinology and Metabolism 288 E573-E584. (https://doi.org/10.1152/ajpendo.00454.2004)

Bendall AJ, Hu G, Levi G \& Abate-Shen C 2003 Dlx5 regulates chondrocyte differentiation at multiple stages. International Journal of Developmental Biology 47 335-344.

Bhushan A, Itoh N, Kato S, Thiery JP, Czernichow P, Bellusci S \& Scharfmann R 2001 Fgf10 is essential for maintaining the proliferative capacity of epithelial progenitor cells during early pancreatic organogenesis. Development 128 5109-5117.

Bolger AM, Lohse M \& Usadel B 2014 Trimmomatic: a flexible trimmer for Illumina sequence data. Bioinformatics 30 2114-2120 (https://doi. org/10.1093/bioinformatics/btu170)

Bustin SA, Benes V, Garson JA, Hellemans J, Huggett J, Kubista M, Mueller R, Nolan T, Pfaffl MW \& Shipley GL 2009 The MIQE guidelines: minimum information for publication of quantitative real-time PCR experiments. Clinical Chemistry 55 611-622. (https://doi.org/10.1373/ clinchem.2008.112797)

Chen Y, Yu H, Pask AJ, Fujiyama A, Suzuki Y, Sugano S, Shaw G \& Renfree MB 2018 Hormone-responsive genes in the SHH and WNT/ $\beta$ catenin signaling pathways influence urethral closure and phallus growth. Biology of Reproduction. (https://doi.org/10.1093/biolre/ioy117)

Cheng CM, Cohen M, Wang J \& Bondy CA 2001 Estrogen augments glucose transporter and IGF1 expression in primate cerebral cortex. FASEB Journal 15 907-915. (https://doi.org/10.1096/fj.00-0398com)

Chew KY, Pask AJ, Hickford D, Shaw G \& Renfree MB 2014 A Dual Role for SHH during Phallus Development in a Marsupial. Sexual Development 8 166-177. (https://doi.org/10.1159/000357927)

Church DR, Lee E, Thompson TA, Basu HS, Ripple MO, Ariazi EA \& Wilding G 2005 Induction of AP-1 activity by androgen activation of the androgen receptor in LNCaP human prostate carcinoma cells. Prostate 63 155-168. (https://doi.org/10.1002/pros.20172)

Coveney D, Shaw G \& Renfree MB 2001 Estrogen-induced gonadal sex reversal in the tammar wallaby. Biology of Reproduction 65 613-621. (https://doi.org/10.1095/biolreprod65.2.613)

Coveney D, Shaw G, Hutson JM \& Renfree MB 2002 Effect of an antiandrogen on testicular descent and inguinal closure in a marsupial, the tammar wallaby (Macropus eugenii). Reproduction 124 865-874. (https://doi.org/10.1530/rep.0.1240865)

Donjacour AA, Thomson AA \& Cunha GR 2003 FGF-10 plays an essential role in the growth of the fetal prostate. Developmental Biology 261 39-54. (https://doi.org/10.1016/S0012-1606(03)00250-1)

Dravis C, Yokoyama N, Chumley MJ, Cowan CA, Silvany RE, Shay J, Baker LA \& Henkemeyer M 2004 Bidirectional signaling mediated by 
ephrin-B2 and EphB2 controls urorectal development. Developmental Biology 271 272-290. (https://doi.org/10.1016/j.ydbio.2004.03.027)

Duan C \& Xu Q 2005 Roles of insulin-like growth factor (IGF) binding proteins in regulating IGF actions. General and Comparative Endocrinology 142 44-52. (https://doi.org/10.1016/j.ygcen.2004.12.022)

Fernandez MF, Olmos B, Granada A, López-Espinosa MJ, MolinaMolina J-M, Fernandez JM, Cruz M, Olea-Serrano F \& Olea N 2007 Human exposure to endocrine-disrupting chemicals and prenatal risk factors for cryptorchidism and hypospadias: a nested case-control study. Environmental Health Perspectives 115 8-14. (https://doi.org/10.1289/ ehp.9351)

Goff L, Trapnell C \& Kelley D 2012 cummeRbund: analysis, exploration, manipulation, and visualization of Cufflinks high-throughput sequencing data. $R$ Package Version 2.

Gredler ML, Seifert AW \& Cohn MJ 2015 Tissue-specific roles of Fgfr2 in development of the external genitalia. Development 142 2203-2212. (https://doi.org/10.1242/dev.119891)

Grimberg A \& Cohen P 2000 Role of insulin-like growth factors and their binding proteins in growth control and carcinogenesis. Journal of Cellular Physiology 183 1-9. (https://doi.org/10.1002/(SICI)10974652(200004)183:1<1::AID-JCP1>3.0.CO;2-J)

Harada M, Omori A, Nakahara C, Nakagata N, Akita K \& Yamada G 2015 Tissue-specific roles of FGF signaling in external genitalia development. Developmental Dynamics 244 759-773. (https://doi.org/10.1002/ dvdy.24277)

Haraguchi R, Suzuki K, Murakami R, Sakai M, Kamikawa M, Kengaku M, Sekine K, Kawano H, Kato S \& Ueno N 2000 Molecular analysis of external genitalia formation: the role of fibroblast growth factor (Fgf) genes during genital tubercle formation. Development 127 2471-2479.

Haraguchi R, Mo R, Hui C, Motoyama J, Makino S, Shiroishi T, Gaffield W \& Yamada G 2001 Unique functions of Sonic hedgehog signaling during external genitalia development. Development 128 4241-4250.

Hart A, Papadopoulou S \& Edlund H 2003 Fgf10 maintains notch activation, stimulates proliferation, and blocks differentiation of pancreatic epithelial cells. Developmental Dynamics 228 185-193. (https://doi.org/10.1002/dvdy.10368)

Henderson NA, Cooke GM \& Robaire B 2006 Region-specific expression of androgen and growth factor pathway genes in the rat epididymis and the effects of dual $5 \alpha$-reductase inhibition. Journal of Endocrinology 190 779-791. (https://doi.org/10.1677/joe.1.06862)

Hewitt SC, Li Y, Li L \& Korach KS 2010 Estrogen-mediated regulation of Igf1 transcription and uterine growth involves direct binding of estrogen receptor $\alpha$ to estrogen-responsive elements. Journal of Biological Chemistry 285 2676-2685. (https://doi.org/10.1074/jbc.M109.043471)

Hsieh MH, Breyer BN, Eisenberg ML \& Baskin LS 2008 Associations among hypospadias, cryptorchidism, anogenital distance, and endocrine disruption. Current Urology Reports 9 137-142. (https://doi. org/10.1007/s11934-008-0025-0)

Huynh H, Yang X \& Pollak M 1996 Estradiol and antiestrogens regulate a growth inhibitory insulin-like growth factor binding protein 3 autocrine loop in human breast cancer cells. Journal of Biological Chemistry 271 1016-1021. (https://doi.org/10.1074/jbc.271.2.1016)

Hwa V, Oh Y \& Rosenfeld RG 1999 The insulin-like growth factor-binding protein (IGFBP) superfamily 1. Endocrine Reviews 20 761-787. (https:// doi.org/10.1210/edrv.20.6.0382)

Kalus W, Zweckstetter M, Renner C, Sanchez Y, Georgescu J, Grol M, Demuth D, Schumacher R, Dony C, Lang K \& Holak AT 1998 Structure of the IGF-binding domain of the insulin-like growth factorbinding protein-5 (IGFBP-5): implications for IGF and IGF-I receptor interactions. EMBO Journal 17 6558-6572. (https://doi.org/10.1093/ emboj/17.22.6558)

Kamanga-Sollo E, Pampusch M, Xi G, White M, Hathaway M \& Dayton W 2004 IGF-I mRNA levels in bovine satellite cell cultures: Effects of fusion and anabolic steroid treatment. Journal of Cellular Physiology 201 181-189. (https://doi.org/10.1002/jcp.20000)

Kerr JE, Beck SG \& Handa RJ 1996 Androgens selectively modulate C-fos messenger RNA induction in the rat hippocampus following novelty. Neuroscience $\mathbf{7 4}$ 757-766. (https://doi.org/10.1016/03064522(96)00219-9)

Koike H, Ito K, Takezawa Y, Oyama T, Yamanaka H \& Suzuki K 2005 Insulin-like growth factor binding protein-6 inhibits prostate cancer cell proliferation: implication for anticancer effect of diethylstilbestrol in hormone refractory prostate cancer. British Journal of Cancer 92 1538-1544. (https://doi.org/10.1038/sj.bjc.6602520)

Kojima S, Mulholland DJ, Ettinger S, Fazli L, Nelson CC \& Gleave ME 2006 Differential regulation of IGFBP-3 by the androgen receptor in the lineage-related androgen-dependent LNCaP and androgen-independent C4-2 prostate cancer models. Prostate 66 971-986. (https://doi. org/10.1002/pros.20420)

Laron Z \& Klinger B 1998 Effect of insulin-like growth factor-I treatment on serum androgens and testicular and penile size in males with Laron syndrome (primary growth hormone resistance). European Journal of Endocrinology 138 176-180. (https://doi.org/10.1530/eje.0.1380176)

Laron Z, Pertzelan A \& Mannheimer S 1966 Genetic pituitary dwarfism with high serum concentation of growth hormone - a new inborn error of metabolism? Israel Journal of Medical Sciences 2 152-155.

Le H, Arnold JT, McFann KK \& Blackman MR 2006 DHT and testosterone, but not DHEA or E2, differentially modulate IGF-I, IGFBP-2, and IGFBP-3 in human prostatic stromal cells. American Journal of Physiology: Endocrinology and Metabolism 290 E952-E960. (https://doi. org/10.1152/ajpcell.00339.2005)

Leihy MW, Shaw G, Renfree MB \& Wilson JD 2002 Administration of $5 \alpha$ androstane- $3 \alpha, 17 \beta$-diol to female tammar wallaby pouch young causes development of a mature prostate and male urethra. Endocrinology 143 2643-2651. (https://doi.org/10.1210/endo.143.7.8917)

Leihy MW, Shaw G, Wilson JD \& Renfree MB 2004 Penile development is initiated in the tammar wallaby pouch young during the period when $5 \alpha$-androstane- $3 \alpha, 17 \beta$-diol is secreted by the testes. Endocrinology 145 3346-3352. (https://doi.org/10.1210/en.2004-0150)

Leihy MW, Shaw G, Wilson JD \& Renfree MB 2011 Development of the penile urethra in the tammar wallaby. Sexual Development 5 241-249. (https://doi.org/10.1159/000334053)

Levy JB \& Husmann DA 1996 Micropenis secondary to growth hormone deficiency: does treatment with growth hormone alone result in adequate penile growth? Journal of Urology 156 214-216. (https://doi. org/10.1016/S0022-5347(01)66003-8)

Lu W, Luo Y, Kan M \& McKeehan WL 1999 Fibroblast growth factor-10 a second candidate stromal to epithelial cell andromedin in prostate. Journal of Biological Chemistry 274 12827-12834. (https://doi. org/10.1074/jbc.274.18.12827)

Matsushita S, Suzuki K, Ogino Y, Hino S, Sato T, Suyama M, Matsumoto T, Omori A, Inoue S \& Yamada G 2015 Androgen regulates Mafb expression through its $3^{\prime}$ UTR during mouse urethral masculinization. Endocrinology 157 844-857. (https://doi.org/10.1210/en.2015-1586)

Menzies BR, Shaw G, Fletcher TP, Pask AJ \& Renfree MB 2012 Maturation of the growth axis in marsupials occurs gradually during post-natal life and over an equivalent developmental stage relative to eutherian species. Molecular and Cellular Endocrinology 349 189-194. (https:// doi.org/10.1016/j.mce.2011.10.016)

Merlo GR, Zerega B, Paleari L, Trombino S, Mantero S \& Levi G 2004 Multiple functions of Dlx genes. International Journal of Developmental Biology 44 619-626.

Miyagawa S, Moon A, Haraguchi R, Inoue C, Harada M, Nakahara C, Suzuki K, Matsumaru D, Kaneko T Matsuo I et al. 2009 Dosagedependent hedgehog signals integrated with $\mathrm{Wnt} / \beta$-catenin signaling regulate external genitalia formation as an appendicular program. Development 136 3969-3978. (https://doi.org/10.1242/dev.039438)

Nakano K, Fukabori Y, Itoh N, Lu W, Kan M, Mckeehan WL \& Yamanaka H 1999 Androgen-stimulated human prostate epithelial growth mediated by stromal-derived fibroblast growth factor-10. Endocrine Journal $\mathbf{4 6}$ 405-413. (https://doi.org/10.1507/endocrj.46.405)

Nassar N, Bower C \& Barker A 2007 Increasing prevalence of hypospadias in Western Australia, 1980-2000. Archives of Disease in Childhood 92 580-584. (https://doi.org/10.1136/adc.2006.112862)

Nikolova Z, Djonov V, Zuercher G, Andres AC \& Ziemiecki A 1998 Cell-type specific and estrogen dependent expression of the receptor tyrosine kinase EphB4 and its ligand ephrin-B2 during mammary gland morphogenesis. Journal of Cell Science 111 2741-2751.

Nishida H, Miyagawa S, Vieux-Rochas M, Morini M, Ogino $Y$, Suzuki K, Nakagata N, Choi H-S, Levi G \& Yamada G 2008 Positive regulation of steroidogenic acute regulatory protein gene expression through the interaction between DIx and GATA-4 for testicular steroidogenesis. Endocrinology 149 2090-2097. (https://doi.org/10.1210/ en.2007-1265) 
Ornitz DM, Xu J, Colvin JS, McEwen DG, MacArthur CA, Coulier F, Gao G \& Goldfarb M 1996 Receptor specificity of the fibroblast growth factor family. Journal of Biological Chemistry 271 15292-15297. (https:// doi.org/10.1074/jbc.271.25.15292)

Paulozzi LJ 1999 International trends in rates of hypospadias and cryptorchidism. Environmental Health Perspectives 107 297-302. (https://doi.org/10.1289/ehp.99107297)

Paulozzi LJ, Erickson JD \& Jackson RJ 1997 Hypospadias trends in two US surveillance systems. Pediatrics 100 831-834. (https://doi.org/10.1542/ peds.100.5.831)

Pelzer AE, Bektic J, Haag P, Berger AP, Pycha A, Schäfer G, Rogatsch H, Horninger W, Bartsch G \& Klocker H 2006 The expression of transcription factor activating transcription factor 3 in the human prostate and its regulation by androgen in prostate cancer. Journal of Urology 175 1517-1522. (https://doi.org/10.1016/S00225347(05)00651-8)

Peng L, Wang J, Malloy PJ \& Feldman D 2008 The role of insulin-like growth factor binding protein-3 in the growth inhibitory actions of androgens in LNCaP human prostate cancer cells. International Journal of Cancer 122 558-566. (https://doi.org/10.1002/ijc.23100)

Perriton CL, Powles N, Chiang C, Maconochie MK \& Cohn MJ 2002 Sonic hedgehog signaling from the urethral epithelium controls external genital development. Developmental Biology 247 26-46. (https://doi. org/10.1006/dbio.2002.0668)

Petiot A, Perriton CL, Dickson C \& Cohn MJ 2005 Development of the mammalian urethra is controlled by Fgfr2-IIlb. Development 132 2441-2450. (https://doi.org/10.1242/dev.01778)

Pollak M 2000 Insulin-like growth factor physiology and cancer risk. European Journal of Cancer 36 1224-1228. (https://doi.org/10.1016/ S0959-8049(00)00102-7)

Poole W, Wood JT \& Carpenter S 1981 Confidence intervals for ages of marsupials determined from body measurements. Wildlife Research 8 269-274. (https://doi.org/10.1071/WR9810269)

Renfree MB, Wilson JD, Short Rv, Shaw G \& George FW 1992 Steroid hormone content of the gonads of the tammar wallaby during sexual differentiation. Biology of Reproduction 47 644-647. (https://doi. org/10.1095/biolreprod47.4.644)

Renfree MB, Fenelon J, Wijiyanti G, Wilson JD \& Shaw G 2009 Wolffian duct differentiation by physiological concentrations of androgen delivered systemically. Developmental Biology 334 429-436. (https:// doi.org/10.1016/j.ydbio.2009.07.040)

Renfree MB, Chew KY \& Shaw G 2014 Inducing sex reversal of the urogenital system of marsupials. Differentiation 87 23-31. (https://doi. org/10.1016/j.diff.2013.11.003)

Sahlin L, Norstedt G \& Eriksson H 1994 Androgen regulation of the insulin-like growth factor-I and the estrogen receptor in rat uterus and liver. Journal of Steroid Biochemistry and Molecular Biology 51 57-66. (https://doi.org/10.1016/0960-0760(94)90115-5)

Sane K \& Pescovitz OH 1992 The clitoral index: a determination of clitoral size in normal girls and in girls with abnormal sexual development. Journal of Pediatrics 120 264-266. (https://doi.org/10.1016/s00223476(05)80439-1)

Satoh Y, Haraguchi R, Wright TJ, Mansour SL, Partanen J, Hajihosseini MK, Eswarakumar VP, Lonai P \& Yamada G 2004 Regulation of external genitalia development by concerted actions of FGF ligands and FGF receptors. Anatomy and Embryology 208 479-486. (https://doi. org/10.1007/s00429-004-0419-9)

Schmid CH, Rutishauser J, Schläpfer I, Froesch ER \& Zapf J 1991 Intact but not truncated insulin-like growth factor binding protein-3 (IGFBP-3) blocks IGF I-induced stimulation of osteoblasts: control of IGF signalling to bone cells by IGFBP-3-specific proteolysis? Biochemical and Biophysical Research Communications 179 579-585. (https://doi. org/10.1016/0006-291X(91)91410-E)

Seifert AW, Harfe BD \& Cohn MJ 2008 Cell lineage analysis demonstrates an endodermal origin of the distal urethra and perineum. Developmental Biology 318 143-152. (https://doi.org/10.1016/j.ydbio.2008.03.017)

Shaulian E \& Karin M 2001 AP-1 in cell proliferation and survival. Oncogene 20 2390-2400. (https://doi.org/10.1038/sj.onc.1204383)

Snyder EM, Small CL, Li Y \& Griswold MD 2009 Regulation of gene expression by estrogen and testosterone in the proximal mouse reproductive tract. Biology of Reproduction 81 707-716. (https://doi. org/10.1095/biolreprod.109.079053)
Steinberg Z, Myers C, Heim VM, Lathrop CA, Rebustini IT, Stewart JS, Larsen M \& Hoffman MP 2005 FGFR2b signaling regulates ex vivo submandibular gland epithelial cell proliferation and branching morphogenesis. Development 132 1223-1234. (https://doi.org/10.1242/dev.01690)

Stewart CE, Bates PC, Calder TA, Woodall SM \& Pell JM 1993 Potentiation of insulin-like growth factor-I (IGF-I) activity by an antibody: supportive evidence for enhancement of IGF-I bioavailability in vivo by IGF binding proteins. Endocrinology 133 1462-1465. (https://doi.org/10.1210/ endo.133.3.7689959)

Suk Kim K, Torres CR Jr, Yucel S, Raimondo K, Cunha GR \& Baskin LS 2004 Induction of hypospadias in a murine model by maternal exposure to synthetic estrogens. Environmental Research 94 267-275. (https://doi. org/10.1016/S0013-9351(03)00085-9)

Suzuki K, Haraguchi R, Ogata T, Barbieri O, Alegria O, Vieux-Rochas M, Nakagata N, Ito M, Mills AA Kurita T et al. 2008 Abnormal urethra formation in mouse models of split-hand/split-foot malformation type 1 and type 4. European Journal of Human Genetics 16 36-44. (https://doi. org/10.1038/sj.ejhg.5201925)

Suzuki K, Numata T, Suzuki H, Raga DD, Ipulan LA, Yokoyama C, Matsushita S, Hamada M, Nakagata N Nishinakamura R et al. 2014 Sexually dimorphic expression of Mafb regulates masculinization of the embryonic urethral formation. PNAS 111 16407-16412. (https://doi. org/10.1073/pnas.1413273111)

Sweet RA, Schrott HG, Kurland R \& Culp OS 1974 A study of the incidence of hypospadias in Rochester Minnesota 1940-1970 and a case-control comparison of possible etiologic factors. Mayo Clinic Proceedings 49 52-58. (https://doi.org/10.1016/s0090-4295(74)80198-6)

Team RC. 2014 R: A Language and Environment for Statistical Computing, p 2013. Vienna, Austria: R Foundation for Statistical Computing. (https:// www.r-project.org/)

Trapnell C, Williams BA, Pertea G, Mortazavi A, Kwan G, Van Baren MJ, Salzberg SL, Wold BJ \& Pachter L 2010 Transcript assembly and quantification by RNA-Seq reveals unannotated transcripts and isoform switching during cell differentiation. Nature Biotechnology 28 511-515. (https://doi.org/10.1038/nbt.1621)

Valentinis B, Bhala A, DeAngelis T, Baserga R \& Cohen P 1995 The human insulin-like growth factor (IGF) binding protein-3 inhibits the growth of fibroblasts with a targeted disruption of the IGF-I receptor gene. Molecular Endocrinology 9 361-367. (https://doi.org/10.1210/ mend.9.3.7539889)

Vilela ML, Willingham E, Buckley J, Liu BC, Agras K, Shiroyanagi Y \& Baskin LS 2007 Endocrine disruptors and hypospadias: role of genistein and the fungicide vinclozolin. Urology 70 618-621. (https://doi. org/10.1016/j.urology.2007.05.004)

Vogt PK \& Bos TJ 1990 Jun: oncogene and transcription factor. Advances in Cancer Research 55 1-35.

Wai-Sum O, Short RV, Renfree MB \& Shaw G 1988 Primary genetic control of somatic sexual differentiation in a mammal. Nature 331 716-717 (https://doi.org/10.1038/331716a0)

Weiler S, Rohrbach V, Pulvirenti T, Adams R, Ziemiecki A \& Andres AC 2009 Mammary epithelial-specific knockout of the ephrin-B2 gene leads to precocious epithelial cell death at lactation. Development, Growth and Differentiation 51 809-819. (https://doi.org/10.1111/j.1440169X.2009.01140.x)

Welsh M, Saunders PT, Fisken M, Scott HM, Hutchison GR, Smith LB \& Sharpe RM 2008 Identification in rats of a programming window for reproductive tract masculinization, disruption of which leads to hypospadias and cryptorchidism. Journal of Clinical Investigation $\mathbf{1 1 8}$ 1479-1490. (https://doi.org/10.1172/JCl34241)

Welsh M, MacLeod DJ, Walker M, Smith LB \& Sharpe RM 2010 Critical androgen-sensitive periods of rat penis and clitoris development. International Journal of Andrology 33 e144-e152. (https://doi.org/10.1111/ j.1365-2605.2009.00978.x)

Welsh M, Suzuki H \& Yamada G 2014 The masculinization programming window. Understanding Differences and Disorders of Sex Development (DSD) 27 17-27. (https://doi.org/10.1159/000363609)

Wiig Ø, Derocher AE, Cronin MM \& Skaare JU 1998 Female pseudohermaphrodite polar bears at Svalbard. Journal of Wildlife Diseases 34 792-796. (https://doi.org/10.7589/0090-3558-34.4.792)

Willingham E, Agras K, Vilela M \& Baskin LS 2006 Loratadine exerts estrogenlike effects and disrupts penile development in the mouse. Journal of Urology 175 723-726. (https://doi.org/10.1016/S0022-5347(05)00188-6) 
Witko-Sarsat V, Mocek J, Bouayad D, Tamassia N, Ribeil J-A, Candalh C, Davezac N, Reuter N, Mouthon L Hermine O et al. 2010 Proliferating cell nuclear antigen acts as a cytoplasmic platform controlling human neutrophil survival. Journal of Experimental Medicine. 207 2631. (https:// doi.org/10.1084/jem.20092241)

Wolf CJ, LeBlanc GA, Ostby JS \& Gray LE Jr 2000 Characterization of the period of sensitivity of fetal male sexual development to vinclozolin. Toxicological Sciences 55 152-161. (https://doi.org/10.1093/ toxsci/55.1.152)

Yu H, Jiang H, Xu D, Jin J, Zhao Z, Ma Y \& Liang J 2016 Transcription factor MafB promotes hepatocellular carcinoma cell proliferation through up-regulation of cyclin D1. Cellular Physiology and Biochemistry 39 700-708. (https://doi.org/10.1159/000445661)

Yucel S, Dravis C, Garcia N, Henkemeyer M \& Baker LA 2007 Hypospadias and anorectal malformations mediated by defective Eph/ ephrin signaling. Journal of Pediatric Urology 3 354-363. (https://doi. org/10.1016/j.jpurol.2007.01.199)
Zhang X, Ibrahimi OA, Olsen SK, Umemori H, Mohammadi M \& Ornitz DM 2006 Receptor specificity of the fibroblast growth factor family The complete mammalian fgf family. Journal of Biological Chemistry 281 15694-15700. (https://doi.org/10.1074/jbc.M601252200)

Zheng Z, Armfield BA \& Cohn MJ 2015 Timing of androgen receptor disruption and estrogen exposure underlies a spectrum of congenital penile anomalies. PNAS 112 E7194-E7203. (https://doi.org/10.1073/ pnas.1515981112)

Received 9 August 2018

First decision 18 September 2018

Revised manuscript received 24 September 2018

Accepted 4 October 2018 